\title{
PEMEROLEHAN BAHASA PADA ANAK SUKU SASAK DALAM PERSPEKTIF PSIKOLINGUISTIK
}

\author{
Deny Prasetiawan \\ Program Studi Pendidikan Bahasa Indonesia \\ Program Pascasarjana, Universitas Mataram \\ E-mail: awandeny8@gmail.com \\ DOI: http://dx.doi.org/10.17509/bs_jpbsp.v17i1.6959
}

\begin{abstract}
Abstrak
Pemerolehan bahasa adalah proses pemahaman dan produksi bahasa pada diri anak melalui beberapa tahap mulai dari meraba sampai fasih berbicara. Penelitian ini bertujuan untuk mengkaji kemampuan anak usia empat tahun lima bulan dalam (1) memahami kosakata dasar; (2) mendeskripsikan pemerolehan bahasa pertama pada tataran fonologis, dan; (3) pemerolehan bahasa pada tataran sintaksis. Metode yang digunakan dalam penelitian ini adalah metode simak, cakap, dan dokumentasi. Penelitian ini menggunakan pendekatan psikolingistik. Pendekatan psikolingistik ini mencoba menerangkan hakikat struktur bahasa, dan bagaimana struktur itu diperoleh, digunakan pada waktu bertutur, dan pada waktu memahami kalimat-kalimat dalam pertuturan itu. Pada hakikatnya dalam kegiatan berkomunikasi terjadi proses memproduksi dan memahami ujaran. Hasil dari penelitian ini pemerolehan bahasa pada tataran fonologis dan sintaksis di antaranya responden penelitian sudah cukup baik dalam bertutur, dan tidak terdapat penyimpangan yang berarti dalam tuturan yang dihasilkan. Pemerolehan bahasa anak usia empat tahun lima bulan berada pada tahap perkembangan kalimat. Responden telah mengenal pola dialog, sudah mengerti kapan gilirannya berbicara dan kapan giliran lawan tuturnya berbicara. Responden telah menguasai hukum-hukum tata bahasa yang pokok dari orang dewasa, perbendaharaan kata berkembang, dan perkembangan fonologis dapat dikatakan telah berakhir. Akan tetapi, responden masih mengalami kesulitan dalam pengucapan beberapa konsonan.
\end{abstract}

Kata kunci: pemerolehan bahasa, psikolingistik, fonologi, sintaksis

\section{LANGUAGE ACQUISITION TO A CHILD OF SASAK IN PSYCHOLINGUISTICS PERSPECTIVE}

\begin{abstract}
Language acquisition is the process of understanding and production of language in children through several stages ranging from groping to fluent talk. This study aims to assess the ability of children aged four years and five months in (1) to understand basic vocabulary; (2) describes the acquisition of the first language on a phonological level, and; (3) the acquisition of language on a syntactic level. The method used in this research is the method of referring, proficient, and documentation. This research uses psycholingistic approach. This psycholinguistic approach tries to explain the essence of the structure of language, and how it is acquired, used at the time of speech, and at the time of understanding the sentences in the narrative. In essence in the activities of communication occurs the process of producing and understanding speech. The results of this study of language acquisition on the phonological level and the syntax among the respondents of the study is good enough in speaking, and there are no significant deviations in the resulting speech. Language acquisition of children aged four years and five months is at the stage of the development of a sentence. Respondents have been familiar with the pattern of dialogue, have understood when it was his turn to speak and when it was his turn to speak. Respondents have mastered the basic grammar laws of adults, developing vocabulary, and phonological development can be said to have ended. However, respondents still have difficulty in pronunciation of some consonants.
\end{abstract}

Keywords: language acquisition, psycholinguistics, phonology, syntax 


\section{PENDAHULUAN}

Proses perkembangan manusia dimulai dengan perkembangan prakelahiran, perkembangan fase bayi, perkembangan fase awal kanak-kanak, perkembangan fase akhir kanak-kanak, perkembangan fase remaja, perkembangan tahap dewasa, dan perkembangan lansia. Pembahasan di sini difokuskan pada perkembangan anak usia empat tahun lebih. Pemerolehan bahasa merupakan proses yang berlangsung di dalam otak anak-anak ketika si anak menerima/ memperoleh bahasa pertamanya. Proses itu pun dibagi lagi kepada dua, pertama proses kompetensi, dan kedua, proses performasi. Kompetensi merupakan proses penguasaan tata bahasa yang berlangsung secara tidak disadari. Sedangkan performasi merupakan proses yang lahir dari penguasaan anak tersebut setelah kompetensi dikuasai.

Bahasa pada anak-anak terkadang sukar diterjemahkan, karena anak pada umumnya masih menggunakan struktur bahasa yang masih kacau. Hal ini terjadi karena sebagian anak belum mampu berkomunikasi secara lancar, belum dapat menyebutkan kosa kata yang benar, tidak dapat menjawab pertanyaan guru dan masih mengalami tahap transisi dalam berbicara, sehingga sukar untuk dipahami oleh mitra tuturnya (Delfita, 2012, p.3,).

Untuk menjadi mitra tutur pada anak dan untuk dapat memahami maksud dari pembicaraan anak, mitra tutur harus menguasai kondisi atau lingkungan sekitarnya, maksudnya ketika anak kecil berbicara mereka menggunakan media di sekitar mereka untuk menjelaskan maksud yang ingin diungkapkan kepada mitratutrnya di dalam berbicara. Selain menggunakan struktur bahasa yang masih kacau, anakanak juga cenderung masih menguasai keterbatasan dalam kosakata dan dalam pelafalan fonemnya secara tepat. Lingkungan sangat mempengaruhi perkembangan bahasa anak.

Pemerolehan bahasa yang diartikan sebagai proses yang dilakukan oleh kanakkanak mencapai sukses penguasaan yang lancar serta fasih terhadap bahasa ibu mereka atau yang sering dikenal dengan bahasa yang terbentuk dari lingkungan sekitar. Dalam hal ini pemerolehan bahasa pada anak akan membawa anak pada kelancaran dan kefasihan anak dalam berbicara (Prideni, Sudhita, \& Sudarma, 2014, p.4)

Rentang umur anak di usia balita umumnya mempunyai kemampuan dalam menyerap sesuatu dan ingatan cenderung lebih cepat dibandingkan usia-usia diatas balita. Sehingga dalam usia-usia tersebut sebaiknya mendapatkan pemerolehan bahasa yang baik, anak harus selalu dirangsang dengan sesuatu yang bersifat pedagogig atau pendidikan. Pendidikan bahasa pada anakanak tersebut harus selalu di tingkatkan untuk memperoleh hasil keterampilan berbicara yang baik.

Proses pemerolehan dan penguasaan bahasa pada anak merupakan satu hal yang menarik untuk diteliti. Bagaimana manusia memperoleh bahasa merupakan satu isu yang amat mengagumkan dan sukar dibuktikan. Berbagai teori dari bidang disiplin yang berbeda telah dikemukakan oleh para pengkaji untuk menerangkan bagaimana proses ini berlaku dalam kalangan anak-anak. Memang diakui bahwa disadari ataupun tidak, sistemsistem linguistik dikuasai dengan pantas oleh individu anak-anak walaupun umumnya tidak ada pengajaran formal.

Pemerolehan bahasa atau akuisisi bahasa adalah proses yang berlangsung di dalam otak kanak-kanak ketika dia memperoleh bahasa pertamanya atau bahasa ibunya. Pemerolehan bahasa biasanya dibedakan dengan pembelajaran bahasa. Pembelajaran bahasa berkaitan dengan proses-proses yang terjadi pada waktu seorang kanak-kanak mempelajari bahasa kedua setelah dia memperoleh bahasa pertamanya. Jadi, pemerolehan bahasa berkenaan dengan bahasa pertama, sedangkan pembelajaran bahasa berkenaan dengan bahasa kedua 
(Chaer, 2003, p.167). Setelah tahap vokalisasi, bayi mulai mengoceh (babling). Celoteh merupakan ujaran yang memiliki suku kata tunggal seperti mu dan da. Adapun umur si bayi mengoceh tak dapat ditentukan dengan pasti. Mar'at (2005, p.43) menyebutkan bahwa tahap ocehan ini terjadi pada usia antara 5 dan 6 bulan.

Pemerolehan fonologi pada anak meliputi kemampuan anak menghasilkan bunyi-bunyi bahasa yang berupa vokal dan konsonan walaupun belum dalam bunyi yang sempurna. Bunyi-bunyi tersebut terjadi secara bertahap yaitu:

- Pada usia 6 minggu, anak menghasilkan bunyi-bunyi yang mirip bunyi vokal dan konsonan;

- Pada usia 8-20 minggu, anak berada pada tahap mendekut (cooing);

- Pada usia 6 bulan, anak mencampur bunyi konsonan dan vokal (babbling/celotehan);

- Pada usia 2 tahun, anak melafalkan sebuah dengan konsonan di akhir kata tidak dilafalkan;

Pemerolehan morfologi pada anak adalah pemerolehan bentuk morfem pada anak, baik morfem bebas dalam bentuk kata, maupun dalam bentuk morfem terikat. Namun pemerolehan tersebut lebih sering berupa morfem bebas berupa bentuk dasar atau kata dasar. Beberapa ahli menyatakan pendapatnya mengenai hal tersebut.

Bloom danTardif menyatakan bahwa kelas kata kerja diperoleh lebih awal daripada kelas kata lainnya, dan frekuensi penggunaannya juga lebih tinggi. Gentner menyatakan bahwa kata benda diperoleh lebih awal daripada kata kerja dan frekuensinya pun lebih tinggi (Darjowidjojo, 2005, p.259). Dardjowijojo (2000, p.268), menyatakan pendapatnya berdasarkan penelitiannya, bahwa selama lima tahun pemerolehan leksikon anak didominasi oleh kata benda, diikuti kata kerja pada urutan kedua, kata sifat pada urutan ketiga, serta kata tugas pada urutan berikutnya.
Pemerolehan Sintaksis pada anak adalah pemerolehan unsur bahasa pada anak yang meliputi frase, klausa, dan kalimat, beserta intonasinya. Khususnya dalam ujaran dua kata (UDK) pada anak telah menunjukkan bahwa anak telah menguasai kelas kata sederhana dan mampu secara kreatif memvariasikan fungsinya. Pemerolehan leksikal pada anak adalah penguasaan kosakata yag ada di sekeliling anak. Di mana pun seorang anak berada, dia akan menguasai kosakata yang ada di sekelilingnya dan kosakata yang pada saat itu ada. Anak akan sulit membayangkan benda yang tidak ada di depan mereka, demikian pula, untuk mengungkapkan peristiwa yang telah lalu atau yang akan datang, yang belum terjadi. Leksikon yang dikuasai anak sangat bergantung pada keadaan anak. Anak petani di desa akan lebih awal memperoleh dengan sempurna kata cangkul dan sawah. Akan tetapi, mereka sulit menguasai dengan baik kata krayon dan komputer, seperti anak yang tinggal di kota.

Pemerolehan semantik dilakukan seorang anak dengan mengamati dan mengumpulkan sebanyak-banyaknya informasi yang ada di lingkungannya. Apa yang diamati oleh seluruh panca indranya menjadi pengetahuan dunianya. Berdasarkan pengetahuan dunia inilah seorang anak memperoleh semantik bahasa dunianya dengan cara melekatkan "makna" yang tetap kepada uruan bunyi bahasa tertentu. Ahli-ahli psikologi perkembangan menyatakan bahwa anak-anak memperoleh makna suatu kata dengan cara menguasai fitur-fitur semantik kata satu demi satu sampai dengan semua fitur semantik itu sebagaimana yang dikuasai dikuasai oleh orang dewasa (Chaer, 2003, p.195). Alamsyah (2007, p.21) menyebutkan bahwa anak-anak mengembangkan tingkat gramatikal kalimat yang dihasilkan melalui beberapa tahap, yaitu melalui peniruan, melalui penggolongan morfem, dan melalui penyusunan dengan cara menempatkan katakata secara bersama-sama untuk membentuk 
kalimat.

Secara etimologis, istilah Psikolinguistik berasal dari dua kata, yakni Psikologi dan Linguistik. Seperti kita ketahui kedua kata tersebut masing-masing merujuk pada nama sebuah disiplin ilmu. Secara umum, Psikologi sering didefinisikan sebagai ilmu yang mempelajari perilaku manusia dengan cara mengkaji hakikat stimulus, hakikat respon, dan hakikat proses proses pikiran sebelum stimulus atau respon itu terjadi. Pakar psikologi sekarang ini cenderung menganggap psikologi sebagai ilmu yang mengkaji proses berpikir manusia dan segala manifestasinya yang mengatur perilaku manusia itu. Tujuan mengkaji proses berpikir itu ialah untuk memahami, menjelaskan, dan meramalkan perilaku manusia.

Linguistik secara umum dan luas merupakan satu ilmu yang mengkaji bahasa (Bloomfield, 1928, p.1).Bahasa dalam konteks linguistik dipandang sebagai sebuah sistem bunyi yang arbriter, konvensional, dan dipergunakan oleh manusia sebagai sarana komunikasi. Hal ini berarti bahwa linguistik secara umum tidak mengaitkan bahasa dengan fenomena lain. Bahasa dipandang sebagai bahasa yang memiliki struktur yang khas dan unik. Munculnya ilmu yang bernama psikolinguistik tidak luput dari perkembangan kajian linguistic. Pada mulanya istilah yang digunakan untuk psikolinguistik adalah linguisticpsychology (psikologi linguistik) dan ada pula yang menyebutnya sebagai psychology of language (psikologi bahasa). Kemudian sebagai hasil kerja sama yang lebihterarah dan sistematis, lahirlah satu ilmu baru yang kemudian disebut sebagai psikolinguistik (psycholinguistic). Psikolinguistik merupakan ilmu yang menguraikan proses proses psikologis yang terjadi apabila seseorang menghasilkan kalimat dan memahami kalimat yang didengarnya waktu berkomunikasi dan bagaimana kemampuan berbahasa itu diperoleh manusia (Simanjuntak, 1987, p.1). Aitchison (1984), membatasi psikolinguistik sebagai studi tentang bahasa dan pikiran.
Psikolinguistik merupakan bidang studi yang menghubungkan psikologi dengan linguistik. Tujuan utama seorang psikolinguis ialah menemukan struktur dan proses yang melandasi kemampuan manusia untuk berbicara dan memahami bahasa. Psikolinguis tidak tertarik pada interaksi bahasa di antara para penutur bahasa, yang mereka kerjakan terutama ialah menggali apa yang terjadi ketika individu yang berbahasa.

Fonologi adalah bagian tata bahasa atau bidang ilmu bahasa yang menganalisis bunyi bahasa secara umum. Kridalaksana (2007,p.2) fonologi adalah ilmu tentang bunyi pada umumnya fonetik sedangkan bunyi bahasa diteliti atau di uraikan dalam fonologi. Istilah fonologi, yang berasal dari gabungan kata Yunani phone 'bunyi' dan 'logos' tatanan, kata, atau ilmu' dlsebut juga tata bunyi. Bidang ini meliputi dua bagian. Fonetik, yaitu bagian fonologi yang mempelajari cara menghasilkan bunyi bahasa atau bagaimana suatu bunyi bahasa diproduksi oleh alat ucap manusia.

Fonemik, yaitu bagian fonologi yang mempelajari bunyi ujaran menurut fungsinya sebagai pembeda arti. Bunyi ujaran yang bersifat netral, atau masih belum terbukti membedakan arti disebut fona, sedang fonem ialah satuan bunyi ujaran terkecil yang membedakan arti. Variasi fonem karena pengaruh lingkungan yang dimasuki disebut alofon. Gambar atau lambang fonem dinamakan huruf. Jadi fonem berbeda dengan huruf. Untuk menghasilkan suatu bunyi atau fonem, ada tiga unsur yang penting yaitu : (1) udara, (2) artikulator atau bagian alat ucap yang bergerak, dan (3) Titik artikulasi atau bagian alat ucap yang menjadi titik sentuh artikulator.

Vokal dan Konsonan. Vokal adalah fonem yang dihasilkan dengan menggerakkan udara keluar tanpa rintangan. Konsonan adalah fonem yang dihasilkan dengan menggerakkan udara keluar dengan rintangan. Yang dimaksud dengan rintangan dalam hal ini adalah terhambatnya udara 
keluar oleh adanya gerakan atau perubahan posisi artikulator. Fonem dan Pembuktiannya Fonem adalah satuan bunyi terkecil yang berfungsi membedakan arti. Fonem dapat dibuktikan melalui pasangan minimal. Pasangan minimal adalah pasangan kata dalam satu bahasa yang mengandung kontras minimal. Contoh :

- pola \& rnembedakan /o/ dan $/ \mathrm{u} /{ }^{\circledR}$ pula

- barang \& membedakan /b/ dan $/ \mathrm{p} / \circledR$ parang

Memahami bunyi merupakan sesuatu hal yang dipandang penting dalam pembelajaran bahasa. Seorang peneliti bahasa akan sutit mengidentifikasi bahasa jika ia tidak menguasai bunyi bahasa. Dengan memahami bagaimana suatu kata dibunyikan dengan baik, seorang pembelajar bahasa akan semakin cepat menguasai bahasa yang hendak dipelajari. Oleh sebab itu, penguasaan bunyi dipandang penting dalam pembelajaran bahasa dan penelitian bahasa (Samsuri, 1987, p.91).

Fromkin dan Rodman (1993, p.403) menyebutkan hasil peniruan yang dilakukan oleh si anak tidak akan sama seperti yang diinginkan oleh orang dewasa. Jika orang dewasa meminta sang anak untuk menyebutkan 'He's going out", si anak akan melafalkan dengan "He go out".

Beberapa linguis generatif (Tarigan, 2009 , p. 38) yakin bahwa suatu tata bahasa terdiri atas tiga komponen utama yang masing-masing komponen melukiskan seperangkat kaidah linguistik tertentu, yaitu komponen sintaksis, komponen semantik, dan komponen fonologi. Komponen sintaksis menjumlahkan suatu perangkat tali simbol tata bahasa yang tidak terbatas banyaknya, masing-masing dengan pemerian struktural yang tepat. Komponen semantik beroperasi pada rangkaian formatif bersamasama dengan pemerian strukturalnya yang menghasilkan suatu interpretasi semantik bagi setiap tali atau untaian. Komponen fonologi memetakan setiap tali sintaksis menjadi gambaran ciri-ciri fonetik yang paling terperinci, yaitu menyajikan setiap kalimat dengan ucapannya.

Dari deskripsi di atas dapat dinyatakan bahwa pemerolehan bahasa anak merupakan suatu proses yang berlangsung terus-menerus secara bertahap. Pemerolehan bahasa seseorang dapat dinilai atau dilihat dari sistem komunikasi linguistiknya yang berada pada tataran sintaksis, tataran semantik, dan tataran fonologi. Oleh karena itu, penelitian tentang pemerolehan bahasa anak secara mendalam dengan memerhatikan ketiga tataran tersebut terasa sangat penting dilakukan.

Pemerolehan bahasa, masukan merupakan faktor yang sangat penting dan sangat menentukan. Manusia tidak akan dapat menguasai bahasa apabila tidak ada masukan komprehensif. Pandangan mentalistik yang menyatakan bahwa anak telah dibekali dengan bekal kodrati pada saat dilahirkan. Disamping itu, dalam bahasa juga terdapat konsep universal sehingga anak secara mental telah mengetahui kodratkodrat yang universal. Chomsky (dikutip Dardjowidjojo, 2005, p.244), mengibaratkan anak sebagai entitas yang seluruh tubuhnya telah dipasang tombol serta kabel listrik: mana yang dipencet, itulah yang akan menyebabkan bola lampu tertentu menyala. Jadi, bahasa mana dan wujudnya seperti apa ditentukan oleh input dari sekitar.

Pada waktu dilahirkan, anak hanya memiliki sekitar 20\% dari otak dewasanya. Ini berbeda dengan binatang yang sudan memiliki sekitar $70 \%$. Karena perbedaan inilah maka binatang sudah dapat melakukan banyak hal segera setelah lahi, sedangkan manusia hanya bisa menangis dan menggerakgerakkan badannya. Pada umur 6 minggu, anak mulai mengeluarkan bunyi-bunyi yang mirip dengan bunyi konsonan atau vokal. Bunyi-bunyi ini belum dapat dipastikan bentuknya karena memang belum terdengar jelas. Sementara pada umur 6 bulan, anak mulai mencampurkan konsonan dengan 
vokal sehingga membentuk apa yang ada dalam bahasa Inggri dinnamakan babbling atau celotehan (Dardjowodjojo, 2000, p.63). Celotehan dimulai dengan konsonan dan diikuti oleh sebuah vokal. Konsonan yang keluar pertama adalah konsonan bilabial hambat dan bilabial nasal. Vokalnya adalah /a/.

Teori tata bahasa Pivot, kajian mengenai pemerolehan sintaksis oleh kanakkanak dimulai oleh Braene (1963), Bellugi (1964), Brown dan Fraser (1964), dan Miller dan Ervin (1964). Menurut kajian awal ini ucapan dua kata kanak-kanak ini terdiri dari dua jenis kata menurut posisi dan frekuensi munculnya kata-kata itu di dalam kalimat. Kedua jenis kata ini kemudian dikenal dengan nama kelas Pivot dan kelas terbuka.

Kemudian berdasarkan kedua jenis kata ini lahirlah teori yang disebut teori tata bahasa Pivot. Pada umumnya kata-kata yang termasuk kelas Pivot adalah kata-kata fungsi (function words), sedangkan yang termasuk kelas terbuka adalah kata-kata isi (contents words) atau kata penuh (full words) seperti katakata berkategori nomina dan verba.

Tabel.1 Ciri-ciri umum kedua jenis kata ini adalah sebagai berikut:

\begin{tabular}{|c|c|}
\hline Kelas Pivot & Kelas Terbuka \\
\hline 1. Terdapat pada awal atau akhir kalimat & Dapat muncul pada awal dan akhir kalimat \\
\hline 2. Jumlahnya terbatas, tetapi sering muncul & $\begin{array}{l}\text { Jumlahnya tidak terbatas, sehingga tidak begitu } \\
\text { seiring muncul }\end{array}$ \\
\hline 3. Jarang muncul anggota baru (kata baru) & Sering muncul anggota baru (kata baru) \\
\hline 4. Tidak pernah muncul sendirian & Bisa muncul sendirian \\
\hline $\begin{array}{l}\text { 5. Tidak pernah muncul bersama dalam satu } \\
\text { kalimat }\end{array}$ & $\begin{array}{l}\text { Bisa muncul bersama dalam satu kalimat, atau } \\
\text { juga dari kelas pivot }\end{array}$ \\
\hline $\begin{array}{l}\text { 6. Tidak punya rujukan sendiri, tetapi selalu } \\
\text { menujuk pada kata-kata lain dari terbuka. }\end{array}$ & Mempunyai rujukan sendiri. \\
\hline
\end{tabular}

Berdasarkan data yang dimuat pada kolom kelas pivot dan kelas terbuka di atas, dapat diketahui perbedaan satu sama lainnya. Tentang hal ini, diberikan contoh kata seperti kata want adalah kata pivot pada posisi awal kalimat, sedangkan kata milk adalah kata terbuka yang muncul pada posisi akhir kalimat.

Anak-anak membangun struktur dan fungsi pada waktu yang bersamaan. Sebaiknya mereka belajar lebih banyak struktur, maka mereka memperoleh lebih banyak sarana untuk menyampaikan fungsi yang berbedabeda. Dan sebaiknya mereka mempelajari banyak fungsi, maka mereka memperluas pemakaian tempat berbagai struktur diterapkan. Seiring perkembangan usia anak, bahasa yang diperolehnya pun tidak sematamata digunakan untuk menyampaikan keinginan atau kehendaknya saja, tetapi juga digunakan sebagai sarana berkomunikasi. Ketika anak belajar berbahasa, dia akan mendengarkan terlebih dahulu kata-kata atau kalimat yang diucapkan oleh kedua orang tuanya atau orang lain di sekitarnya. Kata-kata dan kalimat yang diujarkan orang lain dihubungkan dengan proses, kegiatan, benda, dan situasi yang ia saksikan. Ini berarti bahwa anak-anak menghubungkan hal yang dia dengar melalui proses pikirannya (Pateda,1990, p.63).

Merujuk pada pemaparan di atas, penelitian ini bertujuan untuk: (1) mengkaji kemampuan anak usia empat tahun lima bulan dalam memahami kosakata dasar; (2) mendeskripsikan pemerolehan bahasa pertama anak usia empat tahun lima bulan pada tataran fonologi, dan; (3) memperoleh data kemampuan pemerolehan bahasa anak usia empat tahun lima bulan pada tataran sintaksis.

\section{METODE}

Objek penelitian dalam penelitian ini adalah seorang anak perempuan berusia empat tahun lima bulan bernama Aditia Ramadani. Aditia dilahirkan di keluarga yang dwibahasawan yaitu bahasa Sasak dan bahasa Indonesia. 
Ayah dan ibu Nadya menggunakan bahasa Sasak dan bahasa Indonesia dalam percakapan sehari-hari. Akan tetapi Aditia hanya bisa menggunakan dan memahami bahasa Indonesia saja, dalam penelitian ini hanya akan diteliti pemerolehan bahasa Indonesianya saja.

Penelitian ini dilakukan di halaman rumah pada malam hari di jalan Sunan Maulana Malik Ibrahim no. 18 Blok AA Kodya Asri Jempong Baru Mataram. Peneliti merekam situasi objek ketika sedang berinteraksi dengan peneliti, menggunakan video kamera. Penelitian ini menggunakan metode observasi (metode simak) dan metode cakap dan dokumentasi. Metode simak yang dilakukan dengan cara merekam kemudian mentranskripsikan hasil simakan yang diperoleh. Sedangkan metode cakap dilakukan dengan peneliti terlibat percakapan dengan Aditia selaku objek penelitian secara langsung. Selanjutnya dilakukan pendokumentasian dengan menggunkan video kamera supaya data yang didapatkan lebih valid dan akurat.

\section{HASIL DAN PEMBAHASAN}

Aditia Ramadani atau yang kerap dipanggil dengan Adit adalah anak kedua dari dua bersaudara. Ia lahir pada tanggal 11 Juli 2011. Ayahnya adalah seorang Polisi dan ibunya seorang Karyawan. Adapun lokasi penelitian ini adalah kelurahan Kodya Asri Jempong Baru Mataram. Adit sudah bersekolah di Paud Mata Bangsa. Apabila bermain masih bersifat merusak atau mencacah-cacah barang misalnya kertas yang disobek-sobek. Ia suka mencoba bereksplorasi tentang barangbarang yang ia temui dan ingin menemukan apakah kegunaan dari barang tersebut atau digunakan sesuai imajinasinya dan sesuai dengan tokoh dalam film yang sering ditontonnya seprti, Batman, Superman, Robot, dan Naruto. Dalam berinteraksi ia sudah mulai agak lancar dalam berbicara walaupun kejelasan vocalnya masih belum terbaca secara jelas. Adapun perbendaharaan kata sudah mulai meningkat dan sering ia mengulangi kata-kata yang kita lontarkan atau yang ia dengar. Dan ia juga sering menanyakan apa ini namanya? Apa itu? siapakah dia? maksudnya apa? dan bahkan ia juga sudah mampu menjawab pertanyaanpertanyaan sederhana.

\section{a. Pemerolehan pada Tataran Fonologi Transkrip Data I}

Paman: namanaya siapa?

Adit: Aditia Lamadani

Paman: Adit sekolah dimana?

Adit: PAUD Mata Bangsa

Paman: kelas berapa?

Adit: paud A

Paman: ini warna apa?

Adit: walna ping

Paman: kalau yang ini?

Adit: walna bilu sama colkat

Paman: siapa nama ibu dan bapaknya?

Adit: Eda, bapak adit namanya Alwan Wijaya

Tabel 2. Proses fonologis yang dialami responden

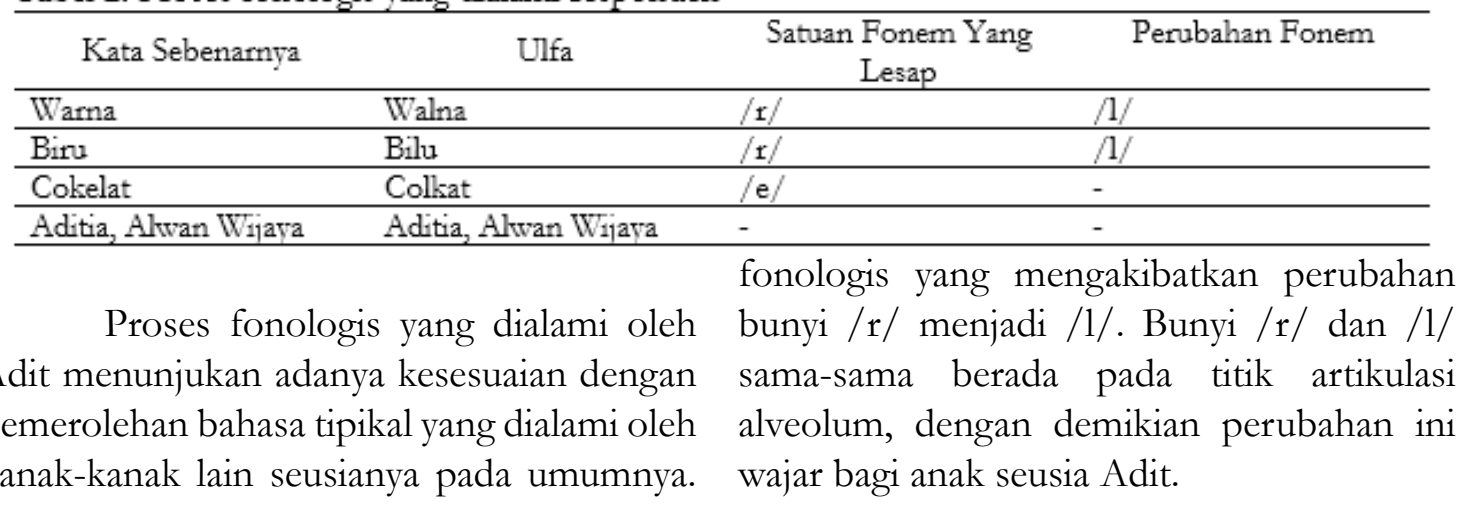

Dari hasil analisis Adit mengalami proses 


\section{b. Pemerolehan pada Tataran Sintaksis Transkrip Data II}

Paman: siapa nama ibu gurunya?

Adit: adit manggilnya bunda

Paman: siapa aja nama bundanya?

Adit: bunda mimi, bunda amel, sama

bunda dayah

Paman: ada yang jomblo gak?

Adit: bunda mimi belum nikah

Paman: adit gak ngaji?

Adit: $\mathrm{mmm}$ belum ajak adit ngaji

Paman: adit udah disunat?

Adit: belum, satu tambah satu berapa?

Paman: dua, sebutkan hewan yang bisa terbang

Adit: batman, bulung, supelmen, kuda, lobot, nglibet gak bisa telbang, sama bulung melpati

Paman: hewan apa yang ada di air?

Adit: buaya, ikan laut, kula-kula, kepiting, laba-laba

Paman: adit suka lagu apa?

Adit; pelangi-pelangi

Paman: cobak dinyanyikan dulu

Adit: pelangi-pelangi alangkah indahmu, melah kuning ijau di langit yang bilu, pelangi-pelangi ciptaan Tuhan

Pemerolehan bahasa Nadya pada tataran sintaksis sudah cukup baik. Hal ini terlihat dari data yang didapatkan. Nadya sudah bisa membuat kalimat yang bersifat deklaratif, interogatif, imperatif. Kemudian menempatkannya pada situasi yang tepat. Contoh kalimat bersifat deklaratif yang dibuat Nadya tampak pada kutipan peristiwa tutur berikut.

Paman: adit gak ngaij?

Adit: $\mathrm{mmm}$ belum ajak adit ngaji

Kalimat tutur diatas menggambarkan Adit sudah dapat memberitakan sesuatu kepada orang lain. Dalam kalimat tutur di atas Adit memberitakan kepada Pamannya bahwa dia belum pernah pergi belajar mengaji.

Adit: belum, satu tambah satu berapa?

Paman: dua, sebutkan hewan yang bisa terbang
Kalimat tutur di atas menggambarkan Adit membuat kalimat yang bersifat interogatif. Adit sudah bisa menanyakan sesuatu pada pamannya. Dalam kalimat tersebut, Adit menggunakan kata berapa.

Paman: siapa nama ibu gurunya?

Adit: adit manggilnya bunda

Kalimat imperatif memiliki makna memberikan perintah untuk melakukan sesuatu sehingga tanggapan yang diharapkan berupa tindakan dari orang yang diperintahnya. Dalam kalimat di atas, Adit ingin pamannya memberikan tanggapan berupa tindakan yaitu menggunakan kata bunda.

Kalimat yang dibuat Nadya sudah cukup baik, namun dalam proses menghasilkan ujaran, Nadya mengalami sedikit kesulitan dalam tahap pengolahan sintaksis yang akan diujarkannya. Contohnya dalam kutipan peristiwa tutur berikut.

Paman: dua, sebutkan hewan yang bisa terbang

Adit: Batman, bulung, Supelmen, kuda, lobot, nglibet gak bisa telbang, sama bulung melpati

Dalam kalimat tutur di atas, Adit mencoba menjawab pertanyaan yang diberikan pamannya. Jawaban yang diberikan sudah benar seprti bulung melpati, meskipun masih ada beberapa jawaban yang agak menyimpang karena mungkin pengaruh dari tontonan sehari-hari seperti Batman, Supelmen, Lobot.

Fungsi bahasa pada anak usia empat tahun lima blan ada tiga yaitu: (1) fungsi informasi yang berfungsi untuk menyampaikan pesan atau amanat kepada orang lain, (2) fungsi eksplorasi untuk menjelaskan suatu hal, perkara, dan keadaan, dan (3) fungsi persuasi untuk mempengaruhi atau mengajak orang lain untuk melakukan atau tidak melakukan sesuatu secara baikbaik. 
Jadi, bahasa ibu adalah bahasa pertama yang dikuasai manusia sejak awal hidupnya melalui interaksi dengan sesama anggota masyarakat bahasanya, seperti keluarga dan masyarakat lingkungan. Hal ini menunjukkan bahasa pertama (B1) merupakan suatu proses awal yang diperoleh anak dalam mengenal bunyi dan lambang yang disebut bahasa. Apabila dalam proses awal menunjukkan pemahaman dan penghasilan yang baik dari keluarga dan lingkungan bahasa yang diperolehnya, proses pemerolehan bahasa selanjutnya akan mendapatkan kemudahan. Tahapan-tahapan berbahasa ini memberikan pengaruh yang besar dalam proses pemerolehan bahasa anak. Pemerolehan bahasa adalah proses pemahaman dan penghasilan (produksi) bahasa pada diri anak melalui beberapa tahap mulai dari meraba sampai fasih berbicara.

\section{SIMPULAN}

Pemerolehan bahasa pada tataran fonologi dan sintaksis Aditia selaku objek penelitian sudah cukup baik. Tidak terdapat penyimpangan yang berarti dalam tuturan yang dihasilkan. Pemerolehan bahasa anak usia empat tahun lima bulan berada pada tahap perkembangan kalimat. Anak sudah mengenal pola dialog, sudah mengerti kapan gilirannya berbicara dan kapan giliran lawan tuturnya berbicara. Anak telah menguasai hukum-hukum tata bahasa yang pokok dari orang dewasa, perbendaharaan kata berkembang, dan perkembangan fonologi dapat dikatakan telah berakhir. Mungkin masih ada kesukaran pengucapan beberapa konsonan namun segera akan berhasil dilalui anak.

\section{DAFTAR RUJUKAN}

Alamsyah, T. (1997). Pemerolehan bahasa kedua. Diktat Kuliah Program S-2. Banda Aceh: Universitas Syiah Kuala.

Brown, D. (2008). Prinsip pembelajaran dan pengajaran bahasa. Kedutaan Besar Amerika Serikat. Jakarta.

Chaer, A. (2003). Psikolinguistik: kajian teoretik. Jakarta: Rineka Cipta.

CD-Rom. Diakses dari: http://educare.efkipunla.net (Generated: 26 July, 2009, 06:28)

Dardjowidjojo, S. (2010). Psikolinguistik pengantar pemahaman bahasa manusia. Jakarta: Unika Atma Jaya.

Delfita, R. (2012). Meningkatkan kemampuan berbahasa anak melalui permainan gambar dalam bak pasir di taman kanak-kanak bina anaprasa mekar sari padang. Jurnal Pesona PAUD Vol.1, No.1, bal. 3.

Fromkin, V., \& Rodman, R. (1993). An introduction to language. Florida: Harcourt Brace Jovanovich Collage.

Mar'at, S. (2005). Psikolinguistike Suatu Pengantar. Bandung: PT Refika Aditama.

Pateda, M. (1990). Aspek-aspek Psikolinguistik. (Cetakan Pertama). Yogyakarta: Nusa Indah.

Prideni, N.K., Sudhita, I.W.R., \& Sudarma, I.K. (2014). Penerapan metode bermain peran berbantuan media kartu gambar untuk meningkatkan kemampuan berbahasa anak. e-journal PG-PAUD Universitas Pendidikan Ganesha Jurusan Pendidikan Guru Pendidikan Anak Usia Dini, Volume 2 No 1 Tabun 2014. 